\title{
GENDER DAN RESILIENSI MATEMATIS SISWA SMP DALAM PEMBELAJARAN SCIENTIFIC BERBANTUAN VBA EXCEL
}

\author{
Puji Nurfauziah $^{1}$, Nelly Fitriani ${ }^{2}$ \\ 1,2 IKIP Siliwangi \\ 1 zielazuardi@gmail.com \\ 2 nhe.fitriani@gmail.com
}

\begin{abstract}
ABSTRAK
Tujuan dari penelitian ini adalah untuk menelaah resiliensi matematis siswa SMP dalam pembelajaran matematika dengan menggunakan pembelajaran scientific berbantuan VBA Excel di Kabupaten Bandung Barat yang dilihat berdasarkan gender. Subjek dari penelitian ini yaitu siswa kelas IX yang berjumlah 31 siswa, yaitu 15 siswa laki-laki dan 16 siswa perempuan. Instrument yang digunakan dalam penelitian ini yaitu angket resiliensi dengan 20 pernyataan dari enam indicator yaitu 1) Sikap tekun,yakin/ percaya diri, bekerja keras, tidak mudah menyerah menghadapi masalah, kegagalan dan ketidakpastian, 2) Berkeinginan bersosialisasi, mudah memberi bantuan, berdiskusi dengan sebayanya, dan beradaptasi dengan lingkungan, 3) Memudahkan ide/cara baru dan mencari solusi kreatif terhadap tangtangan, 4) Menggunakan pengalaman kegagalan untuk membangun motivasi diri, 5) Menunjukan rasa ingin tahu, merefleksi, meneliti, mamanfaatkan beragam sumber, dan 6) Memiliki kemampuan berbahasa, mengontrol diri dan sadar akan perasaannya. Penelitian ini merupakan penelitian kuantitatif dengan metode perbedaan dua rerata. Data angket ditransformasi dari data ordinal menjadi data interval dengan menggunakan method of successive interval (MSI). Setelah data ditransformasi, kemudian data angket resiliensi matematis diuji statistik dengan menggunakan software SPSS 16. Berdasarkan hasil analisis data, diperoleh kesimpulan bahwa terdapat perbedaan resiliensi matematis siswa laki-laki dan siswa perempuan yang pembelajarannya menggunakan pembelajaran scientific berbantuan VBA Excel. Siswa perempuan mendominasi seluruh indicator resiliensi matematis, dan terlihat signifikan pada indicator ke-2 yaitu Berkeinginan bersosialisasi, mudah memberi bantuan, berdiskusi dengan sebayanya, dan beradaptasi dengan lingkungan.
\end{abstract}

Kata Kunci : Gender, Resiliensi Matematis, Pembelajaran Scientific, VBA Excel

\begin{abstract}
The purpose of this study was to examine the mathematical resilience of junior high school students in mathematics learning using VBA EXCEL assisted scientific learning in West Bandung Regency which was viewed by gender. The subjects of this study were class IX students, which numbered 31 students, namely 15 male students and 16 female students. The instruments used in this study were questionnaire resilience with 20 statements from six indicators namely 1) Attitude diligent, confident / confident, working hard, not giving up easily facing problems, failure and uncertainty, 2) Desiring to socialize, easy to give help, discuss with peers, and adapt to the environment, 3) Facilitate new ideas/ ways and find creative solutions to challenges, 4) Use experience failure to build self-motivation, 5) Showing curiosity, reflecting, researching, utilizing various sources, and 6) Having language skills, self-control and awareness of his feelings. This research is a quantitative study with a two-mean difference method. Questionnaire data is transformed from ordinal data into interval data using the method of successive interval (MSI). After the data is transformed, then the questionnaire mathematical resilience data is tested
\end{abstract}


statistically using SPSS 16. Based on the results of data analysis, it can be concluded that there are differences in the mathematical resilience of male and female students learning using VBA Excel assisted scientific learning. Female students dominate all indicators of mathematical resilience, and appear to be significant at the second indicator, namely wanting to socialize, easy to provide assistance, discuss with their peers, and adapt to the environment.

Keywords: Gender, Mathematical Resilience, Scientific Learning, VBA Excel.

\section{PENDAHULUAN}

Penerapan kurikulum 2013 saat ini dilandasi dengan tantangan masa depan yang berupa Globalisasi: WTO, ASEAN Community, APEC, CAFTA; Masalah lingkungan hidup; Kemajuan teknologi informasi; Konvergensi ilmu dan teknologi; Ekonomi berbasis pengetahuan; Kebangkitan industri kreatif dan budaya; Pergeseran kekuatan ekonomi dunia; Pengaruh dan imbas teknosains; Mutu, investasi dan transformasi pada sektor pendidikan dan Materi TIMSS dan PISA (Kemendikbud, 2014). Berdasarkan dari tatantangan masa depan tersebut, maka kurikulum 2013 memiliki tujuan, yaitu siswa diharapkan memiliki kemampuan tingkat tinggi (high order thinking skills) (Kemendikbud, 2016; Rosmaiyadi, 2017), agar dapat berkompetisi dan menyesuaikan diri dengan perkembangan ilmu pengetahuan dan teknologi.

Berangkat dari tuntutan kurikulum 2013 tersebut, siswa dituntut agar menjadi aktif dan kritis dengan mengimplementasikan pendekatan scientific sebagai suatu kemampuan, bukan suatu pendekatan pembelajaran saja (Kemendikbud, 2016). Artinya, siswa harus siap dalam menghadapi tantangan perkembangan zaman dengan mengintegrasikan pendekatan pembelajaran yang terdapat di dalam kurikulum 2013 dengan kehidupan sehari-hari. Hal tersebut sesuai dengan Kemendikbud (2012) bahwa " Kurikulum diarahkan kepada proses pengembangan, pembudayaan dan pemberdayaan peserta didik yang berlangsung sepanjang hayat yang diimplementasikan dalam sikap, keterampilan, dan pengetahuan dasar yang dapat digunakan untuk mengembangkan budaya belajar'. Salah satu mata pelajaran yang berkontribusi dalam kehidupan sehari-hari yaitu mata pelajaran matematika. Karena Mata pelajaran matematika dapat membekali peserta didik dengan kemampuan berpikir logis, analitis, sistematis, kritis, inovatif dan kreatif, serta kemampuan bekerjasama (Rosmaiyadi, 2017).

Salah satu kegiatan pembelajaran yang dianggap membuat siswa aktif dan menyenangkan adalah dengan penerapan pembelajaran yang inovatif yaitu dengan cara mengaplikasikan pembelajaran dengan berbantuan media VBA Excel. Karena VBA Excel merupakan aplikasi yang dirancang menjadi alat matematika yang menjadikan siswa 
menjadi lebih aktif, tidak perlu biaya, dan Microsoft office excel dapat diakses oleh pengguna komputer (Chotimah, Bernard, \& Wulandari, 2018). Selain itu, VBA Excel dapat meningkatkan kemampuan berpikir siswa (Fitriani, Suryadi, \& Darhim, 2018). Hal tersebut sesuai dengan CREET (2010) bahwa kegiatan pembelajaran yang sesuai akan berpengaruh pada resiliensi matematis siswa.

Resiliensi matematis atau ketahanan matematis dapat dikatakan sebagai ketahanan diri, kegigihan, percaya diri dan keinginan untuk berdiskusi dalam menghadapi tantangan dalam pembelajaran matematika (CREET, 2010; Johnston-Wilder \& Lee, 2010; Dilla, Hidayat, \& Rohaeti, 2018). Selain hal tersebut, Graber, Pichon, \& Carabine (2015) mengungkapkan bahwa "Resilience captures how people not only survive a variety of challenging circumstances, but thrive in the face of such adversity". Resiliensi dikatakan bukan hanya bertahan dalam menghadapi tantangan, tetapi kemampuan berkembang di dalam kesulitan. Ulfa (2016) menjelaskan bahwa resiliensi adalah kemampuan bertahan dalam keadaan tertekan, dan bahkan berhadapan dengan kesengsaraan atau trauma yang dialaminya. Ciri dari resiliensi matematis menurut Hendriana, H., Rohaeti, E. E., \& Sumarmo (2017) yaitu 1) Sikap tekun,yakin/ percaya diri, bekerja keras, tidak mudah menyerah menghadapi masalah, kegagalan dan ketidakpastian, 2) Berkeinginan bersosialisasi, mudah memberi bantuan, berdiskusi dengan sebayanya, dan beradaptasi dengan lingkungan, 3) Memudahkan ide/cara baru dan mencari solusi kreatif terhadap tangtangan, 4) Menggunakan pengalaman kegagalan untuk membangun motivasi diri, 5) Menunjukan rasa ingin tahu, merefleksi, meneliti, mamanfaatkan beragam sumber, dan 6) Memiliki kemampuan berbahasa, mengontrol diri dan sadar akan perasaannya.

Siswa yang memiliki resiliensi yang baik, dipastikan akan mampu mengatasi hambatan di dalam pembelajaran matematika (CREET, 2010). Karena resiliensi matematis merupakan sikap positif dalam mempelajari matematika walaupun menghadapi kesulitan (Johnston-Wilder, 2013). Akan tetapi, menurut beberapa penelitian yang telah dilakukan, siswa laki-laki memiliki kemampuan yang lebih dibandingkan dengan perempuan dalam hal prestasi dan ketekukan belajar, McGraw, Lubienski, \& Strutchens ; Sherman \& Fennema; Wilkins and Ma (Johnston-Wilder, 2013). Siswa laki-laki lebih memiliki keyakinan akan kemampuan matematikanya, dapat lebih mengontrol situasi emosi nya (mood, kecemasan) (Nurfauziah, Faudziah, Nuryatin, \& Mustaqimah, 2018). Tetapi menurut beberapa penelitian mengatakan bahwa siswa perempuan lebih cerdas dan memiliki kompetensi yang lebih di dalam matematika (Todor, 2014), serta siswa perempuan lebih berbakat dalam pemecahan masalah matematika, Pajares (Gallagher, 
2004). Berdasarkan hal tersebut, penelitian ini bertujuan untuk melihat perbedaan resiliensi matematis siswa laki-laki dan perempuan dalam pembelajaran scientific berbantuan VBA Excel.

\section{METODE PENELITIAN}

Penelitian ini merupakan penelitian kuantitatif dengan teknik perbedaan dua rerata. Siswa kelas IX yang mendapatkan pembelajaran scientific berbantuan VBA Excel dibagi berdasarkan gender. Setelah kegiatan pembelajaran dengan menggunakan pembelajaran scientific berbantuan VBA Excel berlangsung, siswa diberikan angket resiliensi matematis dengan 20 pernyataan yang meliputi indikator menurut Hendriana, Rohaeti, \& Sumarmo (2017) 1) Sikap tekun,yakin/ percaya diri, bekerja keras, tidak mudah menyerah menghadapi masalah, kegagalan dan ketidakpastian, 2) Berkeinginan bersosialisasi, mudah memberi bantuan, berdiskusi dengan sebayanya, dan beradaptasi dengan lingkungan, 3) Memudahkan ide/cara baru dan mencari solusi kreatif terhadap tangtangan, 4) Menggunakan pengalaman kegagalan untuk membangun motivasi diri, 5) Menunjukan rasa ingin tahu, merefleksi, meneliti, mamanfaatkan beragam sumber, dan 6) Memiliki kemampuan berbahasa, mengontrol diri dan sadar akan perasaannya. Setelah itu, data angket resiliensi matematis ditransformasi terlebih dahulu dari data ordinal menjadi data interval dengan menggunakan MSI (Method Succesive Interval) kemudian diuji normalitas, homogenitas dan uji perbedaan dua rerata, kemudian data tersebut dideskripsikan sesuai gender.

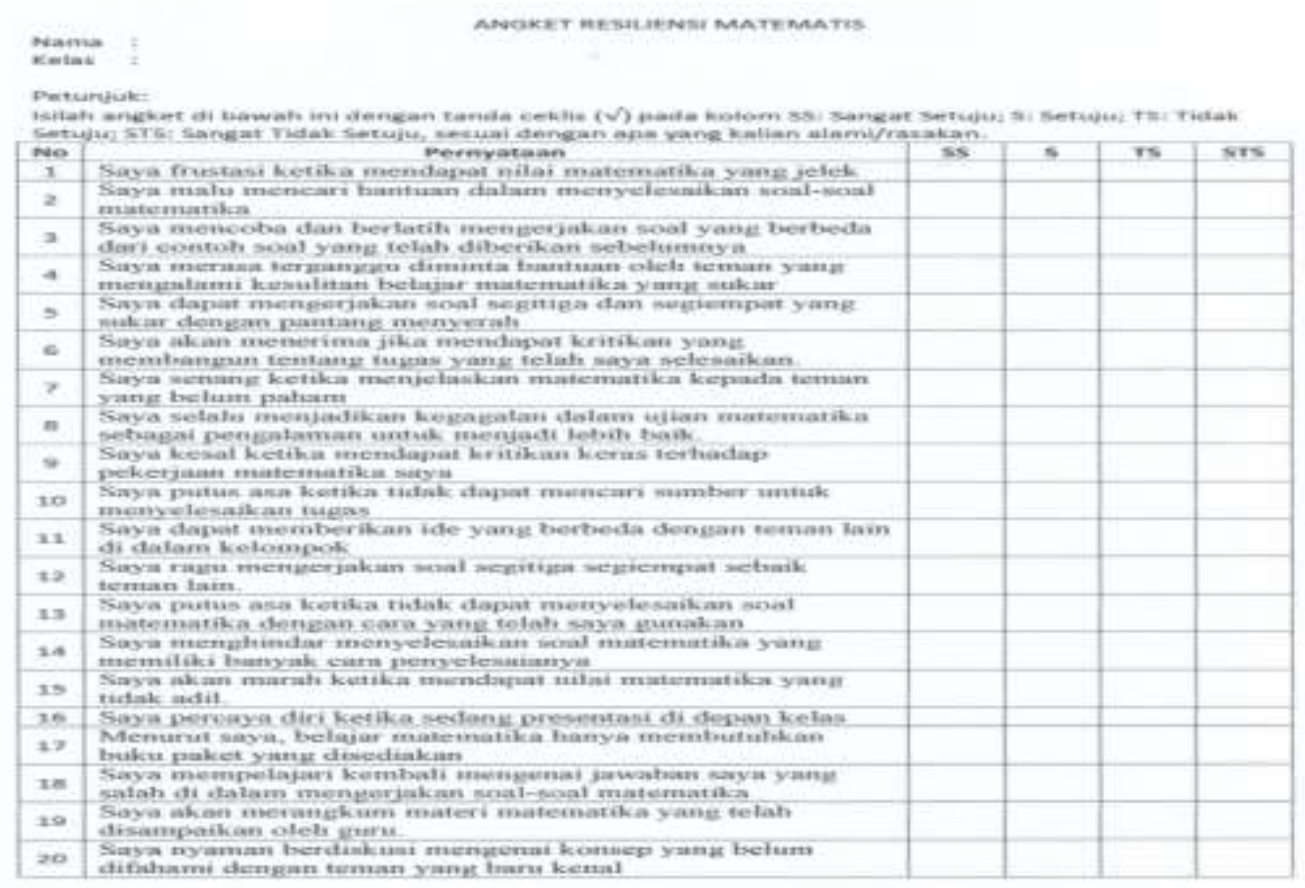

Gambar 1. Angket Resiliensi Matematis 


\section{HASIL DAN PEMBAHASAN}

Tujuan dari penelitian ini adalah untuk mlihat perbedaan resiliensi matematis siswa laki-laki dan perempuan yang pembelajarannya menggunakan pembelajaran scientific berbantuan VBA Excel. Berikut ini adalah deskriptif statistik dari data angket resiliensi siswa perempuan dan laki-laki di kelas IX.

Tabel 1. Deskriptif Statistik Resiliensi Matematis Berdasarkan Gender

\begin{tabular}{ccccc} 
& Gender & N & Mean & Std. Deviation \\
\hline \multirow{2}{*}{ Resiliensi } & Laki-laki & 15 & 60.98 & 5.26 \\
& Perempuan & 16 & 64.54 & 4.36 \\
\hline
\end{tabular}

Berdasarkan hasil tersebut, terlihat bahwa rata-rata resiliensi matematis siswa perempuan lebih besar daripada siswa laki-laki. Untuk memperjelas data tersebut, maka selanjutnya dilakukan pengujian statistik, yaitu uji normalitas, homogenitas dan perbedaan dua rerata dengan menggunakan software SPSS 16.

Tabel 2. Uji Normalitas Resiliensi Matematis Berdasarkan Gender

Kolmogorov-Smirnov ${ }^{\mathrm{a}}$

\begin{tabular}{lrrr} 
& Statistik & df & \multicolumn{1}{c}{ Sig. } \\
\hline Resiliensi Laki-laki & .140 & 15 & $.200^{*}$ \\
Resiliensi Perempuan & .145 & 15 & $.200^{*}$ \\
\hline
\end{tabular}

Berdasarkan Tabel 2, yaitu uji normalitas Resiliensi Matematis berdasarkan gender, diperoleh kesimpulan bahwa kedua data (baik resiliensi siswa laki-laki ataupun resiliensi siwa perempuan) berdistribusi normal. Sehingga pengujian data selanjutnya dilanjutkan dengan uji homogenitas.

Tabel 3. Uji Homogenitas dan Perbedaan Rerata Resiliensi Matematis Berdasarkan Gender

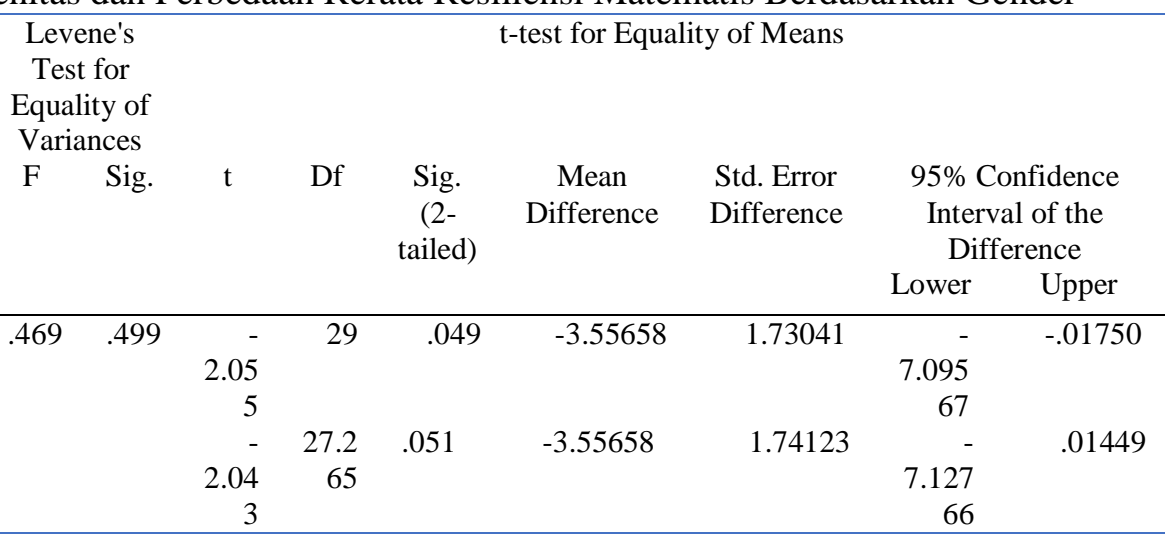

Dapat terlihat di Tabel 3, bahwa kedua data homogen dengan sig. $(0,499)$. Pada uji $\mathrm{t}$ diperoleh nilai sig. 0,049 , berarti sig $<0,05$ artinya terdapat perbedaan resiliensi matematis siswa laki-laki dan siswa perempuan yang menggunakan pembelajaran scientific berbantuan VBA Excel. 
Berdasarkan hasil pengujian statistik diperoleh kesimpulan bahwa terdapat perbedaan resiliensi matematis siswa laki-laki dan siswa perempuan yang menggunakan pembelajaran scientific berbantuan VBA Excel. Walaupun berdasarkan nilai sig. itu sangat kecil sekali perbedaan nya. Akan tetapi dalam hal ini akan dijelaskan lebih lanjut mengenai perbedaan resiliensi tersebut berdasarkan persentase tiap indikator mengenai perbedaan resiliensi matematis siswa laki-laki dan perempuan.

Tabel 4. Persentase Indikator Resiliensi Matematis Berdasarkan Gender

\begin{tabular}{|c|c|c|c|}
\hline No & Indikator & $\begin{array}{l}\text { Laki-laki } \\
(\%)\end{array}$ & $\begin{array}{c}\text { Perempuan } \\
(\%)\end{array}$ \\
\hline 1 & $\begin{array}{l}\text { Sikap tekun,yakin/ percaya diri, bekerja keras, tidak mudah } \\
\text { menyerah menghadapi masalah, kegagalan dan } \\
\text { ketidakpastian }\end{array}$ & 47,54 & 52,46 \\
\hline 2 & $\begin{array}{l}\text { Berkeinginan bersosialisasi, mudah memberi bantuan, } \\
\text { berdiskusi dengan sebayanya, dan beradaptasi dengan } \\
\text { lingkungan }\end{array}$ & 45,05 & 54,95 \\
\hline 3 & $\begin{array}{l}\text { Memudahkan ide/cara baru dan mencari solusi kreatif } \\
\text { terhadap tantangan }\end{array}$ & 47,23 & 52,77 \\
\hline 4 & $\begin{array}{l}\text { Menggunakan pengalaman kegagalan untuk membangun } \\
\text { motivasi diri }\end{array}$ & 47,32 & 52,68 \\
\hline 5 & $\begin{array}{l}\text { Menunjukan rasa ingin tahu, merefleksi, meneliti, } \\
\text { mamanfaatkan beragam sumber }\end{array}$ & 47,90 & 52,10 \\
\hline 6 & $\begin{array}{l}\text { Memiliki kemampuan berbahasa, mengontrol diri dan sadar } \\
\text { akan perasaannya }\end{array}$ & 47,54 & 52,46 \\
\hline
\end{tabular}

Berdasarkan hasil analisis data yang telah dilakukan, didapatkan hasil bahwa terdapat perbedaan resiliensi matematis siswa laki-laki dan perempuan. Berdasarkan dari data deskriptif statistik terlihat bahwa siswa perempuan memliliki rata-rata resiliensi yang lebih tinggi dibandingakan dengan siswa laki-laki. Dari keenam indikator resililiensi, perempuan mendominasi keseluruhan indikator resiliensi. Pada indicator pertama, perempuan memiliki persentase 52,46\% dan laki-laki 45,05\%. Hal tersebut berarti bahwa siswa perempuan lebih tekun,yakin/ percaya diri, bekerja keras, tidak mudah menyerah menghadapi masalah, kegagalan dan ketidakpastian dibandingkan dengan siswa laki-laki. Karena siswa perempuan memiliki kemampuan berempati dan pemecahan masalah yang lebih baik dibandingkan dengan laki-laki (Sunarti, Islamia, Rochimah, \& Ulfa, 2018).

Pada indikator kedua yaitu berkeinginan bersosialisasi, mudah memberi bantuan, berdiskusi dengan sebayanya, dan beradaptasi dengan lingkungan, rata-rata persentase siswa perempuan sebesar 54,95\% dan siswa laki-laki sebesar 45,05\%. Hal tersebut mengindikasikan bahwa siswa perempuan mudah bersosialisasi, beradaptasi dengan lingkungan sekitar. Hal tersebut sesuai dengan Sun \& Stewart (2012) bahwa siswa 
perempuan lebih empati, memiliki tingkat komunikasi, kerjasama dan hubungan yang posititi dengan lingkungan lebih tinggi dari siswa laki-laki.

Selain hal tersebut, pada indikator ketiga yaitu memudahkan ide/cara baru dan mencari solusi kreatif terhadap tantangan diperoleh rata-rata persentase siswa perempuan yaitu $52,77 \%$ dan siswa laki-laki $47,23 \%$. Siswa perempuan memiliki persentase yang lebih tinggi daripada siswa laki-laki. Hal tersebut mengindikasikan bahwa siswa perempuan lebih kreatif di dalam mencari solusi dari tantangan yang diberikan. Artinya siswa perempuan lebih cepat tanggap dalam memamahi permasalahan, karena siswa perempuan lebih baik dalam pemecahan masalah seperti yang telah dijabarkan diatas. Serta hal tersebut sesuai dengan Munandar; Aziz (Aziz, 2006) bahwa kreatifitas siswa perempuan lebih tinggi daripada siswa laki-laki.

Siswa perempuan juga memiliki rata-rata persentase yang lebih tinggi dari pada siswa laki-laki pada indikator keempat yaitu menggunakan pengalaman kegagalan untuk membangun motivasi diri. Siswa perempuan memperoleh rata-rata sebesar 52,68\% dan siswa laki-laki 47,32\%. Berdasarkan nilai tersebut mengindikasikan bahwa siswa perempuan lebih baik dalam mengolah pengalaman negatifnya menjadi suatu motivasi. Bezek (2010) mwngungkapkan ketika perempuan mengalami stress dia akan meminta bantuan teman atau keluarga, tetapi laki-laki akan menyelesaikan stress tersebut dengan sendirinya. Artinya, perempuan akan lebih cepat bangkit dalam stress/kegagalan dibandingkan dengan laki-laki. Hal tersebut sesuai dengan Weberova, Hitka, \& Lizbetinova (2017) “interpersonal relationships, a sense for security, social benefits, the environment, etc. are more important ways of motivating women".

Pada indikator kelima "Menunjukan rasa ingin tahu, merefleksi, meneliti, mamanfaatkan beragam sumber" rata-rata persentase siswa perempuan juga menunjukan persentase yang lebih tinggi dari siswa laki-laki. Persentase untuk siswa perempuan yaitu $52,10 \%$ dan 47,90\% untuk siswa laki-laki. Pada indicator pertama, diketahui bahwa siswa perempuan lebih kreatif dibandingkan dengan siswa laki-laki. Aziz (2006) mengungkapkan bahwa "Perempuan cenderung lebih tinggi pada aspek fluency, originality, dan elaboration, sedangkan pada aspek flexibility laki-laki cenderung lebih tinggi walau perbedaannya tidak terlalu tinggi”. Berdasarkan hal tersebut, perempuan lebih memiliki banyak ide/gagasan dalam menyelesaikan masalah, memberikan gagasan dari cara yang tidak biasa (artinya siswa perempuan memiliki rasa ingin tahu dan memanfatkan sumber yang lebih daripada laki-laki), serta perempuan dapat mengembangkan dan memperkaya gagasan lebih dari pada laki-laki. 
Indikator keenam yaitu Memiliki kemampuan berbahasa, mengontrol diri dan sadar akan perasaannya, perempuan mendapatkan rata-rata indikator lebiih besar daripada lakilaki. Rata-rata indicator perempuan yaitu 52,46\% dan laki-laki 47,54\%. Berdasarkan ratarata indikator tersebut, siswa perempuan memiliki kemampuan berbahasa lebih baik daripada siswa laki-laki. Anak perempuan memiliki kemampuan verbal lebih tinggi daripada laki-laki (Amir, 2018; Saguni, 2014).

\section{KESIMPULAN}

Tujuan dari penelian ini adalah untuk melihat perbedaan resiliensi matematis siswa laki-laki dan siswa perempuan yang menggunakan pembelajaran scientific berbantuan VBA Excel. Berdasarkan hasil analisis data, diperoleh kesimpulan bahwa terdapat perbedaan resiliensi matematis siswa laki-laki dan siswa perempuan yang menggunakan pembelajaran scientific berbantuan VBA Excel. Berdasarkan hasil deskriptif statistik diperoleh rata-rata bahwa persentase siswa perempuan lebih tinggi daripada siswa lakilaki. Siswa perempuan mendominasi keseluruhan indikator resiliensi matematis. Siswa perempuan lebih memiliki: 1) Sikap tekun,yakin/ percaya diri, bekerja keras, tidak mudah menyerah menghadapi masalah, kegagalan dan ketidakpastian, 2) Berkeinginan bersosialisasi, mudah memberi bantuan, berdiskusi dengan sebayanya, dan beradaptasi dengan lingkungan, 3) Memudahkan ide/cara baru dan mencari solusi kreatif terhadap tangtangan, 4) Menggunakan pengalaman kegagalan untuk membangun motivasi diri, 5) Menunjukan rasa ingin tahu, merefleksi, meneliti, mamanfaatkan beragam sumber, dan 6) Memiliki kemampuan berbahasa, mengontrol diri dan sadar akan perasaannya, dibandingkan dengan siswa laki-laki.

\section{REKOMENDASI}

Berdasarkan hasil penelitian ini, peneliti merekomendasikan penelitian lanjutan mengenai resiliensi matematis dan pembelajaran scientific ditinjau dari aspek lain selain gender.

\section{UCAPAN TERIMAKASIH}

Kami ucapkan banyak terimakasih kepada IKIP Siliwangi, karena atas dana yang diberikan melalui hibah kompetitif yang diberikan, penelitian ini dapat terselesaikan dan hasilnya dapat terpublikasi. 


\section{REFERENSI}

Amir, Z. M. (2018). Perspektif Gender Dalam Pembelajaran Matematika. Marwah: Jurnal $\begin{array}{llll}\text { Perempuan, Agama Dan Jender, } & 12(1),\end{array}$ https://doi.org/10.24014/marwah.v12i1.511

Aziz, R. (2006). Mengapa Perempuan Lebih Kreatif Dibanding Laki-Laki? In UIN MALANG.

Bezek, E. (2010). Gender Differences in Resilience in the Emerging Adulthood Population (Rochester Institute of Technology). Retrieved from http://scholarworks.rit.edu/theses Recommended

Chotimah, S., Bernard, M., \& Wulandari, S. M. (2018). Contextual approach using VBA learning media to improve students' mathematical displacement and disposition ability. Journal of Physics: Conference Series, 948(1). https://doi.org/10.1088/17426596/948/1/012025

CREET. (2010). Developing Mathematical Resilience. In Developing Mathematical Resilience (pp. 1-5).

Dilla, S. C., Hidayat, W., \& Rohaeti, E. E. (2018). Faktor Gender dan Resiliensi dalam Pencapaian Kemampuan Berpikir Kreatif Matematis Siswa SMA. Journal of Medives: Journal of Mathematics Education IKIP Veteran Semarang, 2(1), 129. https://doi.org/10.31331/medives.v2i1.553

Fitriani, N., Suryadi, D., \& Darhim, D. (2018). the Students' Mathematical Abstraction Ability Through Realistic Mathematics Education With Vba-Microsoft Excel. Infinity Journal, 7(2), 123. https://doi.org/10.22460/infinity.v7i2.p123-132

Gallagher, A. M. (2004). Gender Differences in Mathematics. Journal of Educational Psychology Journal of Educational Measurement Journal of Experimental Child Psychology.

Graber, R., Pichon, F., \& Carabine, E. Psychological rwsilience State of knowledge and future research agendas., (2015).

Hendriana, H., Rohaeti, E. E., \& Sumarmo, U. (2017). Hard Skills dan Soft Skills Matematik Siswa. Bandung: Refika Aditama.

Hendriana, H., Rohaeti, E. E., \& Sumarmo, U. (2017). Hard skills dan soft skills matematik siswa. Bandung: Refika Aditama.

Johnston-Wilder, S. (2013). Measuring mathematical resilience: an application of the construct of resilience to the study of mathematics. In: AERA 2013, San Ffancisco California, University of Warwick, 2013(May), 1-15. Retrieved from http://wrap.warwick.ac.uk/51559

Johnston-Wilder, S., \& Lee, C. (2010). Developing Mathematical Resilience. BERA Annual Conference 2010, 1-4 Sep 2010 University of Warwick, 1-16. https://doi.org/10.5860/CHOICE.51-2973

Kemendikbud. (2012). DOKUMEN KURIKULUM 2013. In Dokumen Kurikulum 2013 (pp. 1-23).

Kemendikbud. (2014). Implementasi Kurikulum 2013 Konsep dan Penerapan. In Kementrian Pendidikan Dan Kebudayaan.

Kemendikbud. (2016). Kurikulum 2013. In Jendela Pendidikan dan Kebudayaan. https://doi.org/10.1016/0031-9422(91)83742-4

Nurfauziah, P., Faudziah, L., Nuryatin, S., \& Mustaqimah, I. A. (2018). Analisis Self Efficacymatematik Siswa Kelas Viii Smp 7 Cimahi Dilihat Dari Gender (Mathematical Self Efficacy Analysis of Grade Viii Students of Smp 7 Cimahi Viewed From Gender). Jurnal Matematika Dan Pendidikan Matematika, 3(1), 61-70. Retrieved from http://www.journal.unipdu.ac.id/index.php/jmpm/article/view/1046

Rosmaiyadi. (2017). Analisis Kemampuan Berpikir Kritis Matematis Siswa Dalam 
Learning Cycle 7E Berdasarkan Gaya Belajar. Jurnal Aksioma, 6(1), 12-19. https://doi.org/10.24127/AJPM.V6I1.722

Saguni, F. (2014). PEMBERIAN STEREOTYPE GENDER. MUSAWA, 6(2), 195-224.

Sun, J., \& Stewart, D. (2012). Age and Gender Effects on Resilience in Children and Adolescents. International Journal of Mental Health Promotion, 9(4), 16-25. https://doi.org/10.1080/14623730.2007.9721845

Sunarti, E., Islamia, I., Rochimah, N., \& Ulfa, M. (2018). Youth Resiliency: The Differences Based on Region, Poverty, Gender, and School- Type. Jur. Ilm. Kel \& Kons, 11(2), 157-168.

Todor, I. (2014). Investigating "The Old Stereotype" about Boys/Girls and Mathematics: Gender Differences in Implicit Theory of Intelligence and Mathematics Self-efficacy Beliefs. Procedia - Social and Behavioral Sciences, 159(159), 319-323. https://doi.org/10.1016/j.sbspro.2014.12.380

Ulfa, W. D. (2016). Resiliensi pada Mahasiswa yang Memiliki Orangtua Tunggal. Bimbingan Dan Konseling, 5(5).

Weberova, D., Hitka, M., \& Lizbetinova, L. (2017). Age and gender motivating differences of Slovak workers. International Review of Management and Marketing, $7(1), 505-513$. 